\title{
From Streets to Developing Aspirations: How does Collective Action for Education change Marginalised Migrant Youths' Lives?
}

\begin{abstract}
This paper provides an account of migrant youths' experiences of access to education through a social initiative-driven school and highlights how these youths developed pathways of aspirations to work for the good of the community. In doing so, the paper also provides a lens to the issues of migration in Southern Africa and a context in which to understand how collective action for education can deeply transform marginalised migrants' aspirations and offer spaces of equality and agency for change. Drawing on data collected over a span of three years, the paper aims to illustrate how Albert Street School ${ }^{1}$, established as a part of grass-root collective action, supports and impacts on migrants' aspirations and capabilities and how these capabilities lead to aspirations for public good. The narrative methodology used to understand migrant youths' lives and experiences illustrates that collective capabilities have the potential to address different forms of disadvantage and distribute diverse and incommensurable good to local communities.
\end{abstract}

Keywords: aspirations, capabilities, education, migrant youth, social good

\section{Introduction}

Johannesburg is one of the various cities that have always attracted migrants from within and outside South Africa, and in which the number of Zimbabwean migrants has been fast increasing, especially since the early 2000s as a result of the political violence and economic crisis in Zimbabwe. With such a crisis at hand, many Zimbabweans fled to neighbouring South Africa. Within this intensified migration, youths formed a significant portion of those migrating, which came with considerable concern for their wellbeing and the quality of life they would experience in the host country. According to a UNICEF 2009 report, many of that youth migrating to South Africa as child minors fleeing political and economic difficulties in Zimbabwe found themselves in precarious living conditions with no resources or mechanisms of support.

Over the years, the South African government has been active in addressing some of these gaps and have done so in an inclusive and orderly manner, putting in place programmes that would allow undocumented and unofficial migrants to be officially recognised within the country. The Dispensation of Zimbabweans Project (DZP) is one such example. As the high number of undocumented migrants (including children) in the country became apparent as a result of the crisis in Zimbabwe, the South African government put in place the DZP in April 2009. The project was intended to allow undocumented migrants to officialise their status in the country. In essence, as implemented by the Department of Home Affairs, the aim was to regularise the stay of undocumented Zimbabweans by offering them free four-year work and study permits with relaxed requirements (Amit, 2011). However, applicants were required to produce a valid passport and a letter from an employer or a schooling institution in South Africa. While this was a laudable initiative,

\footnotetext{
${ }^{1}$ Authority obtained to use original school name
} 
for some of the Zimbabwean youth, namely those with no means of accessing schooling, the opportunity passed them by because of the basic requirements to benefit from the programme. For example, those seeking work permits had to prove that they were in employment; likewise, for those in school, proof was required that they were enrolled in a schooling institution. As such, this may have been difficult for those who would not have been registered in schools as a result of the lack of resources to access them. Within this challenging context for undocumented migrants, the Central Methodist Church (CMC) in Johannesburg launched a voluntary programme to teach refugee students, most of whom were unaccompanied. This provided an opportunity for the undocumented or refugee youth to attend Albert Street School.

This paper builds on the lives and experiences of the migrant youth who have studied at Albert Street School to provide an account of their journey of gaining access to education through a social collective school (i.e., Albert Street School) and highlight how these migrants (empowered by education) developed pathways of aspirations to work for the good of the community. While the focus of the case study is on undocumented, asylum-seeking and refugee-status Zimbabwean youth, it provides a lens through which to consider the potentials of collective activism to change the lives of migrants through education in Southern Africa. Drawing on data collected between 2014 and 2016 from youths who attended this school, this research is normatively located within the capability approach, and aims to understand how Albert Street School, which was established as a result of a grass-roots initiative, demonstrates collective capabilities and how the school plays a role in migrants' aspirations and capabilities (freedoms), and indeed how these capabilities lead to aspirations that address the public good. We draw on the narrative methodology of migrants and present their accounts to illustrate their aspirations to work for social good despite the corrosive and multiple disadvantages they have experienced. We argue that access to quality and inclusive education can genuinely address different forms of disadvantage and improve one's wellbeing (Nussbaum, 2006), but at the same time acknowledging that some practices and cultural norms perpetuated in education or undemocratically governed and exclusionary educational/school systems can thwart such capabilities and may not provide the transformative space required to provide students with real opportunities (Unterhalter, 2007). By employing the CA, we argue that despite the constrained education aspirations, and within the context of disadvantage, education can lead to the development of aspirations for social good. In the following section, the paper proceeds by briefly introducing the Albert Street School and the collectivity beyond it to show how it is established and operates.

\section{Albert Street School - A school of collective action}

The Central Methodist Church in Johannesburg has been a sacred sanctuary to migrant children of schoolgoing age who were exposed to violence as a result of the 2008 xenophobic attacks on foreigners in South Africa. The church had, for many years, been serving a humanitarian function, providing shelter for a diverse range of disadvantaged individuals (Kuljian, 2013). The church overseer, at the time of the interviews, indicated that 2008 and 2009 were years during which the church was housing up to 5,000 migrants at a time, with some of the participants reporting the fact of sleeping outside the building due to lack of space inside. Many of these migrants had fled the May 2008 xenophobic attacks in the townships surrounding Johannesburg (Seale, 2009). The overcrowding in the church led to outcries from nearby businesses concerned about physical safety and hygiene. However, the argument raised was that the challenges being faced within the vicinity of the church due to these migrants were actually a result of the 
failure of the government to observe both national and international obligations to provide shelter to homeless refugees and asylum seekers (Kuljian, 2013:185). As such, this raised concern about the selfsettling and self-integration of refugees and asylum seekers evident in the literature (see Khan, 2007; Landau, Ramjathan-Keogh \& Singh, 2005). This influx of children, mostly unaccompanied minors, to the church became a cause for concern regarding their educational wellbeing. One of the many challenges rested on the fact that the shelter only provided overnight accommodation and residents had to move out during the day to make way for its day-to-day religious activities. Many individuals therefore had nothing to do during the day except to hang around the streets while others were looking for work. As a result, some of the children were left at risk of being used for or recruited into criminal activities by older people, for example being used to snatch phones for a small payment.

During this time, several skilled and professional adult refugees were resident at the church, and which included qualified teachers. So, the high number of qualified teachers living in the church as refugees and with no jobs resulted in some of these adults volunteering to teach the children that were resident in the church. Albert Street School opened its doors to refugee children on the $7^{\text {th }}$ July 2008, offering learning services from Grade zero to Form six. ${ }^{2}$ The students at the school are encouraged to work hard and take their motivation from successful former students. Tables 1 and 2 show student enrolment, categories and teaching staff at Albert Street School in 2008 (the year the school started) and in 2016.

\section{Table 1 about here}

\section{Table 2 about here}

The school faced many challenges, including difficulty with registering with the relevant educational bodies. Because of the limited human and financial resources, classes started as multi-grade ${ }^{3}$ classes in order to maximise the use of the few available resources. Another challenge was the issue of language, as the teachers were volunteers; it was difficult to get volunteer teachers to teach local South African languages, which is one of the requirements of receiving a full grade 12 (matric) certificate, the formal South African school-leaving certificate. As a result, the school used English as the official language of instruction and registered as an attached centre at the British Council, where students could sit for the Cambridge examinations. In addition to the challenge associated with language, the fact that children did not have official documentation meant that they could not enrol in mainstream schools. Because the majority of these minors were unaccompanied, and thus had no-one to fend for them, there arose a need to provide basic necessities such as the food and living conditions conducive to learning. The teachers had, and continue to take on the multiple roles of teacher, mother, father, brother, sister due to the students' challenging backgrounds, to ensure that they were able to work to the best of their abilities.

\footnotetext{
${ }^{2}$ Form six is the highest grade at high school using the Cambridge education system and is equivalent to Grade 12 in South Africa standards. Albert Street School follows the United Kingdom Cambridge 'form' education system.

${ }^{3}$ For example, form one and form two's in one class.
} 
Thus, although the school has grown from inception both in numbers and in infrastructure (e.g., its library), there remains the challenge of sponsorship and funding and other infrastructure, such as a science laboratory. Unaccompanied minors rely on donations to learn at the school, including registering for the Cambridge exams. Overall, regardless of the challenges, the school has managed to stay afloat as a result of donations from individuals and various non-profit and civil organisations, exemplifying the need and benefit of collective capabilities in addressing developmental concerns. Students at the school are encouraged by the teachers to work hard, and who gain motivation from former students who became successful in life, some who have gone on to work at law firms and banking institutions, for instance. To this end, we reflect on the narratives of the migrants who have studied at Albert Street to date, and track their journeys of gaining access to education, how they benefited from the education offered to them, and how their education led to them developing aspirations to work for the public good and giving back to the community, even in the very precarious context of living.

\section{Developing capabilities in precarious contexts}

We asked how the participants in this research determine education, how education shaped their freedom, and how they (being so empowered by education) developed aspirations to work for the community and people like themselves. We document what this journey of gaining access to education looked like and how it turned into a strong agency and desire to study in order to work for the community and those who are as equally impoverished as they were themselves. We draw on three intersecting concepts to present this journey and to frame our data: conditions enabling access to education, capabilities developed by education, and the formation of aspirations of working for the social good.

First, as Sen (1987) argues, poverty, poor living conditions, and lack of minimum basic needs such as accommodation, food and healthcare can seriously inhibit freedoms, including the ability to be educated (Wilson Strydom and Okkolin, 2016) and to achieve educational wellbeing (Okkolin, 2016). The influence of social contexts, public resources, support of community, family and productive peer relations work as enabling environments for access to education in the Global South (Wilson-Strydom, 2015; Dejaeghere and Lee, 2011); however, within the context of protracted crisis where migrants have no legal access to public resources, or indeed to a supportive family and community environment, access to education is further incumbered by poverty, precarious conditions of migration and living, social immobility and the absence of a supportive environment and social arrangements (Cin and Doğan, 2020; Mkwananzi and WilsonStrydom, 2018). Therefore, we need to ask what the enabling environment for these individuals - one that makes it possible to access education and facilitate educational wellbeing - ought to look like. We need to consider the complex (and sometimes contradictory) relationship between access to education, educational wellbeing and basic needs in contexts where the resources required for one's wellbeing and physical capabilities (Cin, 2017) are only accessible through the education provided by grassroot initiatives and collective capabilities (and which also helps them to acquire education capabilities, as our research shows). It is important to note that in deprived contexts and poor communities, such collective action becomes much more salient and works as an engine for the formation of collective capabilities through the joint efforts of a community or a group of people to achieve a common goal (Evans, 2002; Ibrahim, 2006). In the face of constraining factors, and when people are at odds in ensuring development as freedoms, collective action, or organised collectivities such as grassroot groups, village councils or churches, work as fundamental spaces that encourage people to formulate shared values and pursue them to "achieve what they have reason 
to value." Collective action becomes a poverty-alleviation strategy with the aim of sharing resources, promoting income generation ad pursuing a common goal for the community, even when there is powerful opposition (Evans, 2002). This research exemplifies is one such context. However, accessing education and alleviating poverty through education are not ends in themselves; our data makes it clear that marginalised migrants do not leave social and economic inequalities behind, even if they do ultimately gain access to education. Such inequalities constrain the agency to achieve the desired functionings, pathways, capabilities and aspirations, and individuals may end up with frustrated aspirations which includes a combination of negative external influences (social and structural conditions) and low levels of agency (internal influences) (Mkwananzi, 2019). The capability approach, with its broader focus on the actual livings, beings and doings and agency, can provide a deep understanding of the complexities of how education is played out within the context of disadvantage as further affected by other factors (such as relationship with teachers, quality of education, social relations, sense of community) and forming aspirations (Cin and Doğan, 2020)

Secondly, it is important to understand opportunities and outcomes to consider the ways in which education can lead to an expansion of capabilities, such as the educational, social and collective, which could also be read as a measure of wellbeing and development that contributes to educational justice, particularly in the most precarious contexts (Walker and Unterhalter, 2007; Mkwananzi, 2019; Cin, 2017). The capability approach considers the multi-dimensionality of both development and wellbeing, with an emphasis on the states of being and doing, choices, and the freedom to exercise capabilities of individuals. Education is one of the basic enabling factors that could help individuals achieve what they value, namely their wellbeing goals, by addressing prevailing arrangements and expanding their opportunities (Sen, 1999). The capabilities approach, with its focus on human freedoms and wellbeing, sees education as comprehensive, and as referring to both the economic and intrinsic value of education (Robeyns, 2006; Unterhalter, 2007). It is a multiplier of capabilities, acts as a catalyst of freedoms and opportunities (Nussbaum, 2011; Unterhalter, 2003), and provides both the means to achieve (resources) and enable conversion factors (social relations at schools, access to education, quality of schools, community environment, learning opportunities, schooling, that lead to the conversion of resources into substantive freedoms) to enhance the capacity of young people to determine, pursue and achieve their aspirations (Dubois \& Rousseau, 2008; Hart, 2013), especially within the context of disadvantage (Mkwananzi, 2019). However, education does not necessarily lead to expansion of freedoms and opportunities; only a good quality education, which can be facilitated through enabling factors such as inclusive pedagogical processes or good lecturers (WilsonStrydom and Walker 2017), egalitarian structure, accountability to the larger community (Marginson, 2011), gender-equality seeking practices (Cin, 2017), can play such a role in promoting expansive wellbeing or enhance the livelihoods of people from disadvantaged communities.

Thirdly, one of the outcomes of education in a challenging context is the formation of aspirations (DeJaeghere, 2016; Hart, 2013; Ray, 2006; Appadurai, 2004). Aspirations can be considered the wants, preferences, choices and calculations of individuals and are multidimensional, socially embedded, usually formed through social cohesion, and vary from individual to individual and society to society (Appadurai, 2004). Hart (2008) notes that some aspirations require fulfilment of some given aspiration before the realisation of another and argues that each person experiences different degrees of agency in the determination and fulfilment of their aspirations. For example, young migrants may aspire to gaining access to education; however, before they can realise this aspiration, they may need to fulfil other aspirations such as getting a job to support their families and to pay for schooling. Therefore, depending on one's position 
in the socio-economic hierarchy, aspirations may complement one another or be mutually exclusive (Ray 2006).

Further to the above, while individuals may have their own aspirations, at times they can be persuaded to pursue different aspirations by others (Hart 2013). This may also be seen as an expression of agency where one is actively involved not only in one's own development but also in that of others (Crocker 2009). Such action is indicative of collective aspirations. In many migrant situations, the fluidity of their aspirations is influenced by the new social, cultural and economic practices that they are exposed to in the new country, and which can change their aspirations window significantly.

This aspirations window can also include other associated concerns such as sympathy and commitment to the common good and freedoms, which include the good of individuals and the communities in which they live (Deneulin and Townsend, 2007). The aspiration capability is dynamic and involves high levels of agency, so the point is that migrants empowered by the education they receive are not passive onlookers as they develop aspirations of ethical/imperfect obligation (Sen 2009) to pay back to their new community, work for social good, and help others whose lives were also equally or much more constrained by social inequalities. We argue that leading a life in Albert Street School, in which common goods such as collectivity and solidarity for improving the lives of undocumented migrants are simultaneously generated and enjoyed, also socialise them towards having higher aspirations and ambitions.

Thus, we conceptually frame capabilities by drawing on the intersecting relationships and dynamics of circumstances that enable access to education and develop valued capabilities and developing aspirations for the community within, and through, education. Analysing and capturing the conditions and circumstances that enabled the undocumented migrants access to education and the aspirations developed as an outcome of this education will provide an understanding of the context in which migrant youth make choices and develop agency. As we move to show how the implications of collective action which led to collective capabilities and the formation of public good aspiration, respectively, we follow a dialogical analyses of formation of collective action (and the Albert Street School), the influence of Albert Street School on the migrants and their educational experiences, and the emergence of social good aspirations of 'paying back to the community', all of which are underlined by the intersecting concepts above.

\section{Methods}

We first gained institutional clearance to conduct the study, with subsequent data collection occurring between 2014 and 2016 with migrant youth between 21 and 33 years of age who had accessed the shelter and other services offered by the Central Methodist Church (CMC) using in-depth interviews and focus group discussions. CMC had, up to that stage, been offering different activities such as sewing, baking, and pre-school services, and access to Albert Street School to migrants resident at the shelter. A total of 26 migrant youth, 15 men and 11 women, were interviewed. The audio recorded narratives upon which this paper is based, that ranged between 30 minutes to an hour in length and were later transcribed and thematically analysed using NVivo. This paper is based on 12 of the 15 interviews with the migrant men. Nine of the migrant men had migrated while still minors, and the remainder when they were over eighteen (i.e., adults). Twelve of the fifteen men chosen for this paper had undertaken their secondary education at Albert Street School and had all completed their studies there successfully. Of these men, five were in college/university education (see Table 3) at the time of the interviews. Although they were within five 
years of completing secondary school, those that were not attending college/university still had aspirations to do so.

In addition to the youth, two representatives were interviewed. One of the representatives was affiliated to Albert Street School, while the other was affiliated to both the school and the refugee shelter. The representative of the refugee shelter (Dr. Gasi - pseudonym) was interviewed to gain an overall understanding of the services that were required by migrant youth and if there was a need to further advocate for the provision of such services across different contexts. Additionally, he was also involved in the school council and hence was familiar with two of the major contexts of migrants' lives, the educational aspect and daily survival. The second representative was Dr. Mbatha, who at the time of the interviews was involved in the day-to-day running of the school. The purpose behind interviewing these two representatives in the later stages of the research was to explore the purposes and functions of the school in relation to the migrant youth who attended it. All the interviewed youth were born in Zimbabwe. Table 3 presents the demographics and public good-associated aspirations of the twelve young migrant men who completed their secondary education at Albert Street School.

\section{Table 3 about here}

\section{Findings}

\subsection{From Streets to School: How?}

In a context like South Africa, which has been vulnerable to xenophobic attitudes and violence, finding sustainable ways to peacefully integrate refugees into communities would present as an extreme matter of urgency; as a result, the provision of schooling and learning resources may not thus be viewed as a top priority. For the migrants themselves, finding employment is key to integrating into communities, yet for migrants viewed as child minors, who may not be legally employable, the integration is marred by living, and trying to survive on the streets. Therefore, from this viewpoint, access to any level of education by asylum seekers and refugees would require interventions beyond individual capabilities to gain schooling and would include collective agency and action. Consequently, the inception of Albert Street school may be seen as an intervention to keep migrant youth off the streets by providing them an education that also allowed them access to basic resources. This way, migrant youth would not feel compelled to find employment, which at their age would put them at risk of exploitation. In addition to the opportunity to learn, the youth would value diverse opportunities that could improve their wellbeing. Elton's extract highlights his experiences from living on the streets to getting an education:

We had no place to stay; we were living like street kids until we met two guys who were also sleeping under a bridge there. They told us about the church, and they brought us here. I used to sell mayo at Bree Taxi rank and that capital which I started that business [with], I was given by a taxi driver. He asked what I was doing and I told him I was just roaming around, and he gave me R200 and said "go and buy those things.... need you to sell those things here!" and he showed me the guava juice and then I started [by] buying two packets; within 20 minutes they were finished. I ended up buying lots and the business was so good. I started getting money and that's when I became a better person. That 
is the year Albert Street School was opened, and I went there. I completed my education there in 2010. (Elton)

It is evident from the above extract that the daily experiences of the migrant youth had been marred by challenges to their basic livelihoods. These constrained livelihoods were characterised by a lack of access to the basic capabilities necessary to meet the capability threshold among, inter alia, food shelter, clothing, and access to education. For Elton, making money was one of the motivations to start his education with the aim of aspiring to launch a bigger enterprise, whereas other migrants, who had not been as lucky as Elton in starting and earning a living, mentioned various times in their narratives that the moral and emotional support offered by the teachers and the supportive environment in the church encouraged them to start thinking about education, which has the potential to advance other capabilities. For the youth, access to schooling was viewed as a valued opportunity out their country, as noted by Musa:

I was an unaccompanied minor. I had no parents, I didn't pay fees, and everything was provided, be it food, books, uniform, everything be it stationery. (Musa)

The success of the students is attributed to the dedication and determination of the teachers at the school who, illustrating the role of collective capabilities, pooled together their expertise in various subjects to provide an education to the migrants. Dr. Gasi notes the determination of the teachers:

Teachers at the Albert Street are incredible, and they are devoted, don't earn much money, and are vigilant; you don't get a 100\% pass rate for blowing bubbles, it's the Cambridge and that's a 50\% pass rate and they are incredible. I basically opened up an opportunity and tried to see that we manage the thing as competently as we can, but in terms of the hard work of the education, those teachers are the ones. (Dr. Gasi)

The school functioned despite limited resources such as books, computers, a functional library, and science laboratories, all of which may be seen as necessary for successful teaching and learning. The functioning of Albert Street School reinforces other research on refugees which has also shown that interpersonal relations, intimate environments and social support networks are global mechanisms of support that work as conversion factors in enabling access to education or in helping refugees to engage with the education system (Naidoo et al., 2018; Gateley, 2015; Cin and Dogan, 2020).

\subsection{Why Albert Street School?}

Accessing secondary education, particularly the Cambridge syllabus, was seen as important by the youth because it is an internationally recognised qualification that they could, and would, use for academic progression back home or in other countries. Studying for the Cambridge qualification outside Albert Street School would have been a financial challenge for the youth as it is unlikely that they would have been able to afford the cost of taking up classes and the cost of the examinations. Therefore, being part of Albert Street School meant that their education was dependent on donor funding, which would fund examination costs, something that would not have been guaranteed elsewhere. Since the youth were either 
undocumented or were not yet officially recognised refugees according to law, they would not have been able to access most South African mainstream schools, which would have required official documentation. Additionally, accessing mainstream schools would have come with tuition costs, which again many of the youth would not have been able to afford considering that most of them were unaccompanied minors. Furthermore, studying at mainstream South African schools would have required the migrant youth to study, and write an examination in one of the local languages in order to gain a complete high school certificate, as Musa noted:

I have two friends who left Albert to go to study matric, they were told that 'we need a passport, and you are supposed to learn a home language, so either Sotho, Xhosa, Zulu or any language from SA'. So, if you don't have that then your certificate is not complete, so that is the other challenge, the language one, the other documents, and if you don't know that, it's a big problem (Musa)

Drawing from the above, the Cambridge syllabus provides flexibility in terms of subject choice, particularly language as migrants could choose English or French, depending on which part of Africa they came from. Although most of the youth noted that completing their studies was not without challenges and required extra effort even with the limited resources (for example, no science laboratory), the teachers were creative and were able to make the subjects enjoyable. Furthermore, because the teachers were refugees themselves, they understood the personal and classroom challenges that were experienced by the students. As such, teachers played both parental and teaching roles in classes, making the environment feel like a family setup for the youth. The school's history and purpose made it possible for the teacher to understand and relate to the needs and challenges of the migrant students and, arguably, being surrounded by those who understood their challenges made the students feel welcome despite their lack.

\subsection{Albert Street School as a catalyst for capabilities (capability multiplier)}

In the context of this paper, the examination of migrant youth's capabilities/opportunities is associated with what they are able to do based on the opportunities available to them. Access to education at Albert Street School was an opportunity that the youth did not have before the school opened and, as Sen $(1992 ; 1999)$ asserts, as a characteristic of capabilities, the school presented an excellent opportunity to access a real learning environment.

In Zimbabwe, I wrote only two subjects, I left during exam time, I came and attended Albert Street, and the school was only a year old by that time, so we were only a few, like 15 guys, so we were helped by Albert Street to write our O Levels. We were taken to Albert Street the same day we arrived, and we were welcomed. (Lesley)

$$
* * * *
$$

When I got to Albert, I realised that if I got my O Level certificate I will be at a better place because I [would be able to] use it when I went back to Zimbabwe. Cambridge was all I wanted to do, and I 
could go straight into a university if I get the money at some point, whether in Zimbabwe or here. (Lindani)

We recognise that Albert Street School, as a capability or a freedom, as Sen (1993) highlights, holds intrinsic value for young people. This intrinsic value, as shared some of the young men, was related to gaining respect and recognition from society and the general sense of achievement gained. Other intrinsic dimensions associated with the opportunity to attend the school are related to being able to qualify for university access, the potential to escape poverty, being able to read and write, among other values, in addition to the instrumental opportunities that came with attending the school. So, while we view Albert Street School as a capability in its own right, the narratives show how it advanced other capabilities beyond the school that were valued by the young people. These benefits included meeting basic needs such as providing access to food and clothing and fostering the capability to aspire.

When I heard about the school, they said they would give us food, somewhere to sleep, and somewhere to bathe. When I arrived in Joburg I had spent about two weeks without bathing, only washing my face. When I first went to school, we were very few and there were very few teachers, you could not see that you were at school. It seemed as if we were playing. Truly speaking, I thought I would only stay there for two months until I got work. But then I saw [the] light. (Pete)

\begin{abstract}
$* * *$
When I was at Albert, there were opportunities. For example, different companies and organisations would offer bursaries. Different companies used to take individuals, especially women, for training. I wish there could be more opportunities like that - of different companies, organisations or individuals that are engaged in how they can help other individuals who want to achieve what they want. (Lesley)
\end{abstract}

The extracts above illustrate the intrinsic value for some of the migrant men that resulted from attending Albert Street School. The fact that the young people could bathe and be decently clothed - thereby taking care of their physical wellbeing - meant that they would be representable in society and that this would give them dignity. Access to food improved their wellbeing through being well nourished and healthy. This was in addition to the expansion of their capacity to aspire as they embraced the possibility of accessing post-secondary education as a result of the learning functioning that came with graduating from the school. As the school resources were complemented by individual capabilities and levels of their agency, varying personal circumstances yielded different functionings for each youth. For example, because of high levels of agency, Musa went on to identify a sponsor who sponsored his college education, and because of his confidence and capability to express himself, completed a degree in law. Despite the varying degrees of maximising the limited resources at the school, or the migrant youth, attending a mainstream school may not have provided much value in terms of staying in education as most mainstream schools would not provide free shelter, food, clothing or bathing facilities. As such, staying in school would not have been an 
incentive for migrants, particularly minors, who would need to economically and socially self-integrate into society. As Appadurai (2004) asserts, strengthening the capacity to aspire in individuals with minimal resources, such as marginalised migrants, is vital, as it might help them alter their socio-economic conditions, either in the immediate- or long term. Altering the socio-economic conditions of these individuals can often be noted in the aspirations they form, which in the case of this study related to giving back to the community and aspiring to work for the (community's) good of equally impoverished people like themselves.

\subsection{Aspirations to give back to the community}

The opportunity for the migrant youth to attend school by following an unconventional process altered their otherwise precarious conditions of sleeping on the streets during a time when they were facing diverse challenges. We have also acknowledged that the school was an opportunity that became a capability multiplier. The effect of the collective action taken by the community to start Albert Street School was manifested among the migrant youth as a motivation and desire to give back to society in diverse ways.

From the migrants' stories, the social good aspirations for their home country were in the long term, while their short-term aspirations were associated with socially integrating into South Africa and being treated with respect as people who could make a contribution to society, that is, to be viewed as other than just being a migrant. The youth's long-term aspirations (desired functionings) were attached to the social good of their families and communities. The more personalised aspirations involved taking care of current and future family, such as supporting extended family, in various ways. In terms of giving to the community, aspirations varied from building orphanages, building community colleges to starting businesses that would create employment within their communities.

[I want to] open a children's home, allowing them to pursue their dreams and helping them financially. That is most important for me because even though Dr Gasi will not be there anymore, I will be thanking him for the way that he has brightened our lives, by providing [for] us financially, to finish our O Levels because some of us we left Zimbabwe without finishing our O Levels. (Sipho)

Sipho's extract is representative of the gratitude expressed by all the migrant men who gained the opportunity to pursue their education in a challenging context. All the young men referred to Dr. Gasi as a father figure to them, whose concern about migrants' wellbeing encompassed dimensions such as educational, psychosocial, health, legal, and emotional support - understanding the trauma that the young migrants had experienced. As such, structures were in place at the school through volunteers and NGOs working hand-in-hand to support the students whenever necessary. Furthermore, the students' Cambridge examination fees continue to be sponsored by individual sponsors, some unknown to the migrant youth. Their awareness of the limited possibility of gaining such an opportunity outside Albert Street School instilled the desire to afford similar opportunities to other people in their communities who were experiencing the negative impacts of the various factors of such in their daily lives. While all the migrant men wanted to gain decent employment and give their immediate families (most lived with their 
grandparents) back home a better life, they also wanted to give back to their communities.

I come from a rural area, I told myself if I[had] to come up with a project, I would do it in a rural village. People are interested in farming that side, I'll just do something that has to do with farming like piggery, and poultry. Also, to improve the way people study there, I would open an internet café because in Zimbabwe it's very rare in rural areas, so I would put, maybe ten computers [there] so that students from nearby schools [could] come and learn. By the time they get to [their] O Levels they would know how to use a computer. (Paridzai)

Sipho and Paridzai's snippets are examples of the nature of aspirations of how they want to contribute to the community that has changed their lives, which underlines the conception that aspirations are, to some extent, influenced by the community, environment and culture. This is in line with Appadurai's assertion that aspirations are multidimensional, socially embedded, usually formed through social cohesion, and vary from individual to individual and society to society (Appadurai, 2004). As aspirations may have to do with wants, preferences, choices and calculations, for these migrant youth the opportunity for choice resulted from collective agency. Consequently, the migrant youths' aspirations are interlinked with the community's efforts. The idea of giving back to the community or feeling concerned about their community and the lessadvantaged people around them is also echoed in the research of Cin and Doğan (2020:8), who argue that "this concern (paying back to the community) is most often complementary to one's personal agenda through the understanding that the investment in oneself can lead to an indirect greater good for society." Also, as one's choices are based on one's awareness of one's circumstances, the freedom to make a choice, therefore, becomes a functioning of one's experiences. So, the achievement of making a choice could be of intrinsic (e.g., for the migrant youth it could be the internal satisfaction of being in school rather than being in employment) or instrumental value (e.g., access to networks that may be key to gaining future jobs). In this research, all the desired intrinsic functionings of being socially good proponents (e.g., building orphanages) point to a satisfaction with the associated community efforts. Ultimately, whether or not aspirations are powerful, persistent, resigned or frustrated, as forwarded in Mkwananzi (2019), the decision and choice to formulate them in is often influenced, at least to a certain degree, by societal influence on individual circumstances. Even as the CA reminds us to ask "what is it that the individual values being and doing, and are the necessary opportunities and freedoms to do so available?", in the process of answering this question we ought to acknowledge and take into account the role of society for the presence [or nonpresence] of these opportunities and freedoms (Sen, 2009). For example, at Albert Street School, students continued to receive support at the school through various civil society organisations, non-governmental organisations and individuals. There were opportunities to network with supporters of the school, and such opportunities led to expose Terry, for example, to an opportunity to do job shadowing ${ }^{4}$ for one of lawyers who helped migrants appeal their cases. This experience influenced Terry to pursue a law degree at university, which he was studying for at the time of the interviews. Terry noted:

When I completed my A level I did my job shadow, and I learnt a lot of things and it was very interesting, it was a part of my prize as the best student in 2010 (Terry)

\footnotetext{
${ }^{4}$ Involves observing a professional doing their job
} 
In Terry's case, the school provided a network of resources leading to him choosing to study law, which may not have been possible had he been at another school which did not have to deal with legal matters, as Albert Street had to in relation to migrants.

In this paper, we attest to the creation of the necessary opportunities for migrant youth, which in turn results in socially embedded aspirations. Although the social nature of aspiration does not surprise us per se, as we already know the influence of social settings on aspirations as alluded to by Appadurai (2004) and other scholars (such as Ray, 2006; DeJaeghere, 2016; Hart, 2016; Genicot \& Ray, 2017), the intention of the paper is to reinforce the reciprocal process between individual circumstances (resulting from societal experiences) and societal action (resulting from collective agency) and how the interaction between these agentic structures are reiterative, with the one dependent on the other. Figure 1 illustrates this process.

\section{Figure 1 about here}

As we already derive from literature, it may not be an easy task to separate the individual from the society; a reciprocal relationship exists between the two, which figure 1 attempts to illustrate. The figure illustrates the reciprocal process between individual experiences and the influencing social structures in aspiration formation, and shows the dialectical relationship referred to by Dejhaegre (2016). According to DeJaeghere, one's aspirations are expanded by the agency that one has taking into account the changing social context over time. As such, within a given context, the relationship between agency and aspirations is always in conversation and negotiation, considering the collective in society and what matters at that particular time for a particular group. Through agency, negotiation takes place between individual circumstances and social structures (which may be seen as conversion factors), and the results of this negotiation may help lead to the formation of collective aspirations. Because the relationship is complex and unique for each individual, the process and negotiation may not hold the same experiences as this is then influenced by individual factors such as level of agency, motivation and determination. For example, in the case of Albert Street School, several students were funded through individual sponsorships (philanthropists) which in turn had a positive impact in allowing them to sit the Cambridge exams, expanding their opportunities and changing the way they viewed their daily experiences as migrants. The awareness that someone else was paying for their tuition made them want to 'pay forward' the opportunity by helping other young people in their situation once they became established in employment. Because it is a negotiation relationship, likewise, their daily experiences of being in a foreign land, but having the unique opportunity of being in school, increased some of the youths' levels of agency so that they would not disappoint those who were offering sponsorship to cover the examination costs.

\section{Discussion}

Not every person can derive equal benefit from the same kind opportunity - in this case access to education - and that each individual has different aspirations, but Sen (1999) states that education provides an opportunity that enables freedom. For migrant youth, this freedom, as derived from collective efforts, can be linked to their aspirations of giving back to the community. Thus, the collective agency to help the migrant youth gain access to education is in line with Evan's (2002) assertion that the freedom to do (or access) the things that one has reason to value is often something that cannot be accomplished as individuals, but rather can only be achieved collectively. However, for individuals who are sufficiently privileged to enjoy a full range of capabilities, collective action may seem unnecessary, yet for the less 
privileged attaining such freedom requires collective action and social/environmental support (Cin and Dogan, 2020; Evan, 2002). The importance of such collective action is noted by Pelenc et al. (2013:87), as they assert that "every human being is responsible, but shares this responsibility with others, thus forging a collective capacity for responsible action".

\section{Figure 2 about here}

Figure 2 illustrates how collective agency leads to access to resources (in this case, education), leading to the advancement of other capabilities and resulting in public good aspirations. The long-term achievements, which we refer to in this paper as public good aspirations (presented in Table 1), and that the youth want to realise, are beyond individual benefit. Statements such as 'giving back to the community', 'helping the poor' and 'taking care of my family' are examples of public good aspirations. While generally the conception of aspirations is that they are, to some degree, influenced by community, environment and culture, this case has resulted in these aspirations being influenced by the experiences of the youth as beneficiaries of an initiative that was intended to improve their wellbeing. Ballet et al. (2007:186) note that individuals cannot be viewed as independent of their relationships with other people; they belong to a community and participating in its daily activities impacts on the wellbeing of its individuals. These social interactions, which involve intentionality and obligation towards others, open the way to 'enriching' the individual for him/her to achieve his/her intrinsic value(s). In this light, whatever one achieves or desires to achieve is not always individualistic but may, in fact, be collective. Yet, while aspirations are formed through collective influence, in the 'thick of social life' as Appadurai (2004:67) puts it, we are careful not to present individual aspirations and collective aspirations as two distinct entities. As such, we acknowledge the aspirations process formation to be a reciprocal process with collective influence informing individual desires, and likewise the attainment of these desires centres on the progression of communities and societies of the individuals' choice. For example, Paridzai aspires to be a computer engineer and then give back to his community by building a computer centre. Before this, he mentioned that that he desires 'financial independence and respect', which may be seen as dimensions that improve individual capabilities and freedom. Yet, his aspirations to build a computer centre in his village and make technology accessible to the rural population embody the collective benefit of his aspirations, where his desires shift beyond himself and his family. So, outside the self-wellbeing of buying a home, having a decent job and a decent income, individuals desire progression that leads to the collective experience of a better life. These aspirations are directly or indirectly influenced by the happiness, safety, opportunities and wellbeing of their families and communities, most of whom were left in Zimbabwe. Thus, the nature of collective aspiration emphasises the responsibility we take for the wellbeing of those around us, in the process contributing to the collective good without necessarily disregarding our self-desired wellbeing.

Albert Street School has played a role in positioning the youth to achieve the possibility of giving back to their families and communities and allowing them to gain the skills and knowledge they want to develop through education to be able to work for their communities. As Creegan (2008) asserts, these collective aspirations are important to addressing broader societal inequalities, which is important as a poverty alleviation mechanism. According to Sen (1999), the responsibility that individuals take up needs to relate to the circumstances that are seen around, and this is influenced by the substantive freedoms that one has and we can argue that Albert Street School has provided a certain level of freedom to those who attended 
the school. With such freedom and capability to act, the migrant youth are in a position take up roles that can serve the interests and good of their communities, yet also, based on their freedom, they can choose not to. However, in addition, as a way of expressing gratitude, the migrant youth have made it their responsibility to improve their families and communities as they may be aware that poverty in their families and communities may not only deprive them of their wellbeing, but may also lead to a deprivation in living a responsible life, even towards others. As such, grassroots initiative such as Albert Street School potentially have a wider impact on broader society.

\section{Conclusion}

In this research, we echo Ibrahim's argument (2006) that collective capabilities are formed through social interaction and engagement in collective actions. The mutuality of relationships, communal trust and support, and social factors such as the poverty, the church's initiatives, and the collective conscious of the refugees staying in church to make things better, the social and cultural capital of the refugees (some of whom were qualified teachers) were significant resources enabling to build collective capabilities. Such initiatives implicate the ontology of a relational society (Sen, 1993) and show how the ethical individualism inherent to capabilities can challenge ontological individualism by looking into social, economic, and political forces. Some (Martins, 2007; Smith and Seward, 2009) have argued and conceptualised this interconnectedness between individual and social structures from the relational ontology of incorporating social and individual causes. Smith and Seward (2009) focus on the social aspect of capabilities from an understanding of how societies and individual interact with another to constitute capabilities, whereas Martins (2007) reads the interaction of social structures such churches and government with the individual from a dialectical process where people exploit and transform these structures to form new social environments. However, these perspectives do not drastically differ from the notion of collective capabilities and complement them by highlighting the importance of recognising social structures and how they interact with casual mechanisms, and adds an intersecting perspective to the importance of social relations in the formation of capabilities. Yet, by focussing on the collective capabilities notion posited by Ibrahim (2006), we responded to questions of how, why, to what extent, for whom and by whom collective capabilities are formed.

When we return to Pelenc et al.'s (2013) assertion that while every human being is responsible, sharing this responsibility with others results in a collective agency which naturally forges socially good aspirations. Such collective aspirations allow individuals to act in such a way that potentially develops socially shared aspirations. These collective aspirations are central to addressing wider social inequalities and have the potential to address concerns about poverty that exist in today's society. What the capability approach has allowed us to do is to highlight the role of group action in advancing individual capabilities. We draw the meaning of such action to the relationship between individuals and society and the meanings that the relationship (as illustrated in figures 1 and 2) is a reflection of the African Zulu saying "umuntu ngumuntu ngabantu", namely "a person is a person through other people". We reflect on how such action is key to providing incommensurable goods to others within society to flourish, or at least have the opportunity to pursue what is valuable to them.

From a policy standpoint, although educational policies may continue to exclude certain migrants, the collective action and aspirations exhibited through Albert Street School are an example of the moral and ethical obligation that we, as individuals, have for one another in attempts to create socially just 
environments ourselves. It is the potential impact that the process has on human and social development that policy institutions ought to encouraged to consider creating spaces that are not restrictive to such action, and also provide the necessary support; in the case of Albert Street School, such support may include subsidies from government or the allocation of other educational resources that would make learning a memorable experience.

\section{References}

Amit, R. (2011). The Zimbabwean documentation process: Lessons learned. African Centre for Migration and Society.

Appadurai, A. (2004). The capacity to aspire. In M. Walton \& V. Rao (Eds). Culture and Public Action. Stanford, CA: Stanford University Press (pp. 59-84).

Ballet, J., Dubois, J.L. \& Mahieu, F.R. (2007). Responsibility for each other's freedom: Agency as the source of collective capability. Journal of Human Development, 8(2), 185-201.

Cin, F. M. (2017). Gender Justice, Education and Equality: Creating Capabilities for Girls' and Women's Development. Palgrave: London.

Cin, F. M., \& Doğan, N. (2020). Navigating university spaces as refugees: Syrian students' pathways of access to and through higher education in Turkey. International Journal of Inclusive Education, 115.

Creegan, C. (2008). Opportunity and aspiration: two sides of the same coin? York: Joseph Rowntree Foundation.

Crocker, D. (2009). Ethics of Global Development: Agency, Capability, and Deliberative Democracy. Cambridge: Cambridge University Press.

DeJaeghere, J. (2016). Girls' educational aspirations and agency: imagining alternative futures through schooling in a low-resourced Tanzanian community. Critical Studies in Education, DOI: 10.1080/17508487.2016.1188835.

Dejaeghere, J., \& Lee, S. K. (2011). What matters for marginalized girls and boys in Bangladesh: A capabilities approach for understanding educational well-being and empowerment. Research in Comparative and International Education, 6(1), 27-42.

Dubois, J.L. \& Rousseau, S. (2008). Reinforcing Household's Capabilities as a Way to Reduce Vulnerability and Prevent Poverty in Equitable Terms. In, F. Comim, M. Qizilbash \& S. Alkire (eds).The Capability Approach: Concepts, Measures and Applications. Cambridge: Cambridge University Press (pp. 421-436).

Deneulin S. and Townsend, N. (2007). Public Goods, Global Public Goods and the Common Good, International Journal of Social Economics 34(1-2), 19-36.

Evans, P. (2002). Collective capabilities, culture and Amartya Sen's development as freedom. Studies in Comparative International Development, 37(2), 54-60.

Gateley, D. E. (2015). A policy of vulnerability or agency? Refugee young people's opportunities in accessing further and higher education in the UK. Compare: A Journal of Comparative and International Education, 45(1), 26-46.

Genicot, G., \& Ray, D. (2017). Aspirations and Inequality. Econometrica, (85), 489-519. Available at: https://doi.org/10.3982/ECTA13865.

Greene, M. (1988). The dialectic of freedom. New York, NY: Teachers College Press. 
Hart, C. (2008). What Can Young People Tell Us About Promoting Equality and Inclusion Through Widening Participation in Higher Education in England? Paper presented at the Human Development and Capability Association International Conference, New Delhi, India, 9-13 September 2008.

Hart, C.J. (2013). Aspirations, Education and Social Justice: Applying Sen and Bourdieu. London \& New York: Bloomsbury.

Hart, C.S., 2016, 'How do aspirations matter'? Journal of Human Development and Capabilities 17, 324 341. https://doi.org/10.1080/19452829.2016.1199540.

Ibrahim, S.S. (2006). From individual to collective capabilities: The capability approach as a conceptual framework for self - help. Journal of Human Development, 7(3), 397-416.

Khan, F. (2007). Patterns and policies of migration in South Africa: Changing patterns and the need for a comprehensive approach. Cape Town: University of Cape Town Refugee Rights Project. Available at:

http://www.refugeerights.uct.ac.za/downloads/refugeerights.uct.ac.za/patterns_policies_migration FKhan.doc.

Kuljian, C. (2013). Sanctuary: How an inner-city church spilled onto a sidewalk. Sunnyside: Jacana Media.

Landau, L., Ramjathan-Keogh, K. \& S., Singh (2005). Xenophobia in South Africa and Problems Related to it. Forced Migration Working Paper Series No. 13. University of the Witwatersrand, Forced Migration Studies Programme, Available at: http://www.migration.org.za/working-paper/ workingpaper-13-xenophobia-south-africa-and-problems-related-it.

Marginson, S. (2011) "Higher Education and Public Good.” Higher Education Quarterly 65 (4): $411-$ 433.

Martins, N. (2007). 'Ethics, ontology and capabilities'. Review of Political Economy, 19(1): 37-53.

Mkwananzi, F. \& Wilson-Strydom, M. (2018). Multidimensional disadvantages and educational aspirations of marginalised migrant youth: Insights from the Global South, Journal of Global Ethics, 14 (1), 71-94, DOI: 10.1080/17449626.2018.1496349.

Mkwananzi. F. (2019) Higher Education, Youth and Migration in Contexts of Disadvantage: Understanding Aspirations and Capabilities. London: Palgrave Macmillan.

Naidoo, L., Wilkinson, J., Adoniou, M., \& Langat, K. (2018). Refugee background students transitioning into higher education: Navigating complex spaces. Springer: Singapore.

Nussbaum, M. C. (2006). Education and democratic citizenship: Capabilities and quality education. Journal of Human Development, 7 (3), 385-395.

Nussbaum, M. (2011). Creating Capabilities: The Human Development Approach. Harvard: Harvard University Press.

Okkolin, M-A. (2016). Who decides? Tanzanian Women's Narratives on Educational Advancement and Agency. Gender and Education, DOI: 10.1080/09540253.2015.1124069.

Pelenc, J., Lompo, M. K., Ballet, J., \& Dubois, J. L. (2013). Sustainable human development and the capability approach: Integrating environment, responsibility and collective agency. Journal of Human Development and Capabilities, 14(1), 77-94.

Ray, D. (2006). Aspirations, Poverty, and Economic Change. In A.V. Banerjee, R. Benabo \& D. Mookherjee (Eds). Understanding Poverty. Oxford: Oxford University Press. (pp. 409-421).

Robeyns, I. (2006). Three models of education: Rights, capabilities and human capital. Theory and Research in Education, 4, 69-84. 
Seale, L. (2009). Refugee mayhem in Johannesburg CBD hits Business severely. The Star, March 10, 6. Available at: https://www.security.co.za/news/11809.

Sen, A. (1987) The Standard of Living. The Tanner Lectures on Human Values.

https://tannerlec tures.utah.edu/_documents/a-to-z/s/sen86.pdf

Sen, A. (1993). Capability and well being. In M. Nussbaum \& A. Sen (Eds.), The quality of life (pp. 3053). Oxford: Clarendon Press.

Sen, A. (1999). Development as Freedom. Oxford University Press.

Sen, A. K. (2009). The idea of justice. Harvard University Press.

Smith, M. L., \& Seward, C. (2009). The relational ontology of Amartya Sen's capability approach: Incorporating social and individual causes. Journal of Human Development and Capabilities, 10(2), 213-235.

UNICEF (2009). Zimbabwe education crisis worsens. Available at: http://www.unicef.org/media/media_47915.html.

Unterhalter, E. (2003). The Capabilities Approach and Gendered Education: An Examination of South African Complexities. Theory and Research in Education (1), 7-22.

Unterhalter, E. (2007). Gender, schooling and global social justice. Abingdon: Routledge Taylor Francis.

Walker, M. and Unterhalter, E. (2007). The Capability Approach: It's potential to work in education. In M. Walker \& E. Unterhalter (Eds). Amartya Sen's Capability Approach and Social Justice in Education. New York: Palgrave McMillan (pp. 1-18).

Wilson-Strydom, M. (2015).University Access and Theories of Social Justice: Contributions of the Capabilities Approach. Higher Education, 69 (1), 143-155. DOI:10.1007/s10734-014-9766-5.

Wilson-Strydom, M., \& Okkolin, M. A. (2016). Enabling environments for equity, access and quality education post-2015: Lessons from South Africa and Tanzania. International Journal of Educational Development, 49, 225-233.

Wilson-Strydom, M., \& Walker, M. (2017) "Human Development as an Expansive Perspective on Socially Just Pedagogies and Quality." In Socially Just Pedagogies, Capabilities and Quality in Higher Education, edited by M. Walker and M. Wilson-Strydom, 223-243. London: Palgrave Macmillan. 